\title{
TRADISI PAKAIAN BARU PADA HARI RAYA DI MADURA: STUDI LIVING HADITH
}

\author{
Mohammad Subhan Zamzami \\ Institut Agama Islam Negeri Madura \\ mszamzami@iainmadura.ac.id
}

\begin{abstract}
The living tradition of new outfit on the feast day in Madura which passes down through generations has been considered only as a local tradition, whereas it is basically rooted from the hadith and the practices of the prophet's companions. This article attempts to discuss the hadith on the tradition of the new outfit on the feast day, the Madurese's view of this tradition, and the identification and urgency of this tradition as a living hadith. Based on the theory of acculturation and living hadith, this article concludes that: (a) The hadith about this tradition was narrated by alBukhārī, Muslim, and al-Nasā̄̄í; (b) The Madurese's views on this tradition are varied, even contradictory depending on their perspectives and experiences; and (c) This tradition belongs to a living hadith on its material aspects for its existence seems to be rooted from the hadiths and the practices of the prophet's companions. It reflects elements of obedience, respect, expressions of happiness, compassion, preservation of Islamic tradition, and differentiation between one moment from another.
\end{abstract}

Keywords: Living hadith; new outfit; the feast day; Madura.

\begin{abstract}
Abstrak: Tradisi pakaian baru pada hari raya di Madura merupakan tradisi yang diwariskan lintas generasi yang dianggap hanya sebagai tradisi lokal. Padahal ia berasal dari hadis dan praktik sahabat. Artikel ini mendiskusikan secara deskriptif-analitis hadis tentang tradisi pakaian baru pada hari raya, pandangan masyarakat Madura tentang tradisi ini, identifikasi dan urgensi tradisi ini di Madura sebagai living hadith. Berdasarkan teori akulturasi dan living hadith, artikel ini menyimpulkan bahwa: (a) Hadis tentang tradisi ini diriwayatkan al-Bukhārī, Muslim, dan al-Nasā̄̄i; (b) Pandangan orang Madura tentang tradisi ini beragam, bahkan kontradiktif tergantung pada perspektif dan pengalamannya; dan (c) Tradisi ini merupakan living badith kebendaan pada aspek matan, karena keberadaannya diilhami oleh hadis dan praktik sahabat. Ia mengandung unsur kepatuhan, penghormatan, ekspresi kebahagiaan, kasih sayang, pelestarian tradisi Islam, dan pembedaan antara suatu momentum dari momentum lain.
\end{abstract}

Kata Kunci: Tradisi, pakaian baru, living hadith, hari raya, Madura. 


\section{Pendahuluan}

Semua agama terkait dengan persoalan kebudayaan karena tidak muncul dan berkembang dari ruang hampa, termasuk Islam, sehingga proses akulturasi terjadi; agama memengaruhi budaya dan budaya memengaruhi agama. Dalam hal ini, ulama Suni mewacanakan kaidah usul fikih al-ädah muhakkamah (adat bisa menjelma sebagai hukum atau hukum bermuara dari adat) dan ungkapan al-ma'rüf 'urfan ka almashrüt shartan, wa al-thäbit bi al-'urf ka al-thäbit bi al-nass (sesuatu yang baik menurut adat istiadat adalah seperti syarat yang harus ada, dan sesuatu yang keberadaannya bersifat tetap dalam adat istiadat adalah seperti sesuatu yang keberadaannya bersifat tetap dalam nas). ${ }^{1}$ Sebagian contoh akulturasi ini bisa ditemukan pada saat hari raya Islam, baik Idulfitri maupun Iduladha.

Pada saat hari raya, terutama Idulfitri, sebagian umat Islam di Indonesia, terutama di Madura, memiliki beberapa tradisi unik, seperti mudik, silaturahim atau halal bihalal, ziarah, dan pakaian baru. Namun, mereka tidak menyadari sebagian tradisi yang mereka warisi dari leluhur mereka sebenarnya berasal dari ajaran Islam. Ketidaksadaran ini muncul, karena sebagian tradisi tersebut telah mendarahdaging pada diri mereka, sehingga keberadaannya dianggap sebagai tradisi lokal murni belaka yang sama sekali tidak terkait dengan ajaran Islam. Dalam hal ini, tradisi memakai pakaian baru pada hari raya, baik Idulfitri maupun Iduladha, merupakan bukti terbaiknya. Di Nusantara, tradisi memakai pakaian baru ini disinyalir telah ada sejak zaman Kerajaan Banten pada tahun 1596 M. $^{2}$

Tradisi memakai pakaian baru pada hari raya Idulfitri patut diduga sebagai tradisi yang diilhami oleh sunah Nabi Muhammad. Dugaan ini didukung oleh tiga hadis sahih, yang salah satunya diriwayatkan oleh al-Bukhārī (194-256 H.) dalam Sahịḥ al-Bukhārī. Dia meletakkan hadis ini dalam kitäb al-īidayn (bab dua hari raya) pada bāb

1 Nurcholis Madjid, "Akulturasi Islam dan Budaya Lokal", Paramadina, http://paramadina.or.id/2015/08/07akulturasi-islam-dan-budaya-lokal. Diakses pada 03 Oktober 2017.

${ }^{2}$ Hutomo Dwi, “Sejarah Baru Serba Baru Saat Lebaran Sejak Zaman Kerajaan”, Jadi Berita, http://jadiberita.com/90801/sejarah-baju-serba-baru-saat-lebaran-sejakzaman-kerajaan.html. Diakses pada 09 September 2018.

3 Abū 'Abd Allāh Muhạmmad b. Ismā̄ịl al-Bukhārī, Saḥ̣̄̄ al-Bukhārì (Beirut: Dār Ibn Kathīr, 2002), 231. Muslim (206-261 H.) meriwayatkan hadis yang semakna dengan hadis ini dalam Saḥị̣ Muslim. Abū al-Ḥusayn Muslim b. al-Ḥajjāj al-Qushayrī al-Naysābūrī, Saḥ̄ḥ Muslim (Riyad: Dār al-Mughnī, 1998), 1146. 
fi al-ídayn wa al-tajammul fìh (subbab dua hari raya dan berhias di dalamnya). Berdasarkan penamaan bab dan subbabnya, al-Bukhārī memahami hadis tentang memakai pakaian baru pada hari raya ini sebagai sunah Nabi, karena pemikiran fikih al-Bukhārī tentang hadis terletak pada penamaan bab dan subbabnya. ${ }^{4}$ Meski demikian, tradisi ini juga dilakukan oleh umat Kristiani $^{5}$ dan etnis Tionghoa Konghucu. ${ }^{6}$

Ada dua faktor utama di balik penelitian tentang tradisi pakaian baru di Madura ini penting dilakukan, yaitu: pertama, pada satu sisi, tradisi pakaian baju baru pada hari raya bukan hanya merupakan tradisi yang dilestarikan oleh umat Islam, tetapi dilestarikan juga oleh umat Kristiani dan etnis Tionghoa Kunghucu. Pada sisi lain, keberadaan hadis riwayat al-Bukhārī itu diduga sebagai inspirator tradisi ini, terutama di kalangan umat Islam yang mayoritas tidak menyadarinya sebagai living hadith. Kedua, ulasan tentang tradisi pakaian baru pada hari raya yang ada selama ini hanya merupakan reportase biasa dan bukan merupakan hasil penelitian yang komprehensif. Artikel ini mendiskusikan secara deskriptif-analitis tiga poin utama, yaitu: (a) hadis tentang tradisi pakaian baru pada hari raya; (b) pandangan masyarakat Madura tentang tradisi pakaian baru pada hari raya; dan (c) identifikasi dan urgensi tradisi pakaian baru pada hari raya di Madura sebagai living hadith. Tiga poin ini didiskusikan berdasarkan teori living hadith dan akulturasi.

\section{Living Hadith dan Teori Akulturasi}

Dalam kajian hadis, tradisi yang eksistensinya berasal dari hadis lumrah disebut sebagai living hadith, yaitu hadis Nabi yang senantiasa hidup di tengah masyarakat karena dipraktikkan secara turuntemurun, sehingga menjelma sebagai tradisi setempat. Istilah living hadith dipopulerkan pertama kali oleh Barbara D. Metcalf melalui artikelnya, Living Hadith in Tablighi Jamaah, pada tahun 1993. Menurutnya, istilah ini mencakup dua pengertian, yaitu: (a) penerapan

\footnotetext{
${ }^{4}$ Nūr al-Dīn 'Itr, Manhaj al-Naqd fì Ulüm al-Ḥadìth (Damaskus: Dār al-Fikr, 1979), 254.

5 Erwan, "Memakai Baju Baru", Buletimpintar, www.buletinpillar.org/renungan/memakai-baju-baru. Diakses pada 09 September 2018.

${ }^{6}$ Hasyim Hasanah, "Perayaan Imlek Etnis Tionghoa: Menakar Implikasi PsikoSosilogis Perayaan Imlek bagi Komunitas Muslim di Lasem Rembang," Jurnal Penelitian, Vol. 8, No. 1 (2014), 7.
} 
hadis dalam kehidupan sehari-hari; dan (b) internalisasi hadis tekstualvisual hingga ia menjelma sebagai sesuatu yang hidup. ${ }^{7}$ Fokus kajian dari istilah yang mirip dengan teori 'amal abl al-Madinah dalam mazhab Maliki dan pengembangan dari istilah living sunnab ini adalah praktik, tradisi, ritual, atau perilaku yang bijak-lestari di tengah masyarakat yang bermuara dari hadis. ${ }^{8}$ Living hadith melampaui perdebatan apakah hadis identik dengan tradisi oral sedangkan sunah identik dengan praktik kenabian; hadis merupakan verbalisasi sunah; dan hadis atau sunah merupakan tradisi kenabian, baik bersifat lokal, temporal, maupun universal yang selama ini mengungkung paradigma abl albadith dan abl al-ra'y,' karena living hadith merupakan peralihan dari kajian tentang teks hadis ke kajian tentang resepsi hadis di tengah masyarakat. ${ }^{10}$

Objek material living hadith sama dengan objek material cabang ilmu hadis pada umumnya, tetapi objek formalnya berbeda satu sama lain. Sanad dan matan merupakan objek material living hadith. Namun, dalam living badith, sanad dikaji dari dua unsur dasarnya, yaitu periwayat (rām $\imath$ ) sebagai pelaku dan periwayatan (tahdith) sebagai proses transmisi hadis pada saat menjelma sebagai enkulturasi karena keduanya terkait dengan pelestarian sunah Nabi (iby $\vec{a}^{\prime}$ al-sunnab). Sedangkan matan merupakan objek material living hadith pada saat menjelma sebagai tradisi yang hidup (ibya $\vec{a}$ al-hadith). Secara umum, living hadith mencakup tiga poin utama, yaitu: (a) living badith kebendaan, seperti anggota tubuh, pakaian, asesoris, pedang, alas kaki, dan konsumsi; (b) living hadith humanistis, seperti cara meminum, berkomunikasi, berjalan, dan bekerja; dan (c) living hadith kesosialan, seperti cara hidup yang dilakukan bersama-sama, terstruktur secara sistematis dalam satu kesatuan organisasi atau lembaga, dan

\footnotetext{
7 Jajang A Rohmana, "Pendekatan Antropologi dalam Studi Living Hadis di Indonesia: Sebuah Kajian Awal”, Jurnal Holistic, Vol. 01, No. 02 (2015), 256.

8 Saifuddin Zuhry Qudsy, "Living Hadis: Genealogi, Teori, dan Aplikasi", Jurnal Living Hadis, Vol. 1, No. 1 (2016), 179-180.

9 Munawir, "Ahl Al-Hadith dan Ahl Al-Ra'y: Dari Konstruksi Metodologi Hingga Tipologi Pemahaman Hadis Dialektik", Mutawatir: Jurnal Keilmuan Tafsir Hadith, Vol. 9, No. 2 (2019), 246-247.

10 Muhamad Ali, “Kajian Naskah dan Kajian Living Qur'an dan Living Hadith", Journal of Qur'ān and Hadith Studies, Vol. 4, No. 2 (2015), 150.
} 
berbudaya. ${ }^{11} \mathrm{Hal}$ ini karena living hadith lebih menitikberatkan pada aspek performatif hadis daripada aspek informatifnya.

Living hadith merupakan wujud akulturasi antara budaya lokal dan Islam. Kontak budaya dalam proses difusi, yaitu persebaran elemenelemen kebudayaan, baik sesuatu yang berwujud (tangible) maupun tak berwujud (intangible), melalui proses migrasi individual atau komunal ke komunitas lain dengan pelbagai cara menimbulkan akulturasi. ${ }^{12}$ Akulturasi terjadi karena dua kebudayaan atau lebih yang begitu berbeda berintegrasi, sehingga unsur-unsur budaya asing menyerap ke dalam budaya lokal tanpa menghilangkan identitas keasliannya. ${ }^{13}$ Akulturasi antara budaya lokal dan Islam berbentuk dialogis dan integratif. Di Nusantara, akulturasi dialogis terjadi, misalnya, antara Islam dan budaya Jawa yang berdialog dalam struktur sosio-religi setempat, sedangkan akulturasi integratif terjadi antara Islam dan budaya Melayu, yaitu Islam berkembang dan menyangga struktur politik Melayu ${ }^{14}$ yang terkandung dalam aforisme (adat basandi syarak, syarak basandi Kitabullah/adat bersendikan syariat, syariat bersendikan kitabulah). ${ }^{15}$

\section{Hadis Pakaian Baru pada Hari Raya}

Alquran merupakan kitab suci dan sumber utama ajaran Islam yang meliputi pelbagai aspek kehidupan, baik kehidupan di dunia maupun kehidupan di akhirat. Di antara pelbagai aspek kehidupan di dunia yang disinggung oleh Alquran adalah pakaian. Dalam hal ini, Alquran menggunakan dua kata dasar, yaitu th-y-b (ثيب) dan l-b-s (لبس) (نيب) (لئ). Pertama, terkait dengan kata dasar th-y-b (ثيب), Alquran hanya menggunakan satu kata, yaitu thiyāb dalam delapan ayat, baik ayat

\footnotetext{
11 Ahmad 'Ubaydi Hasbillah, "Objek Kajian Living Quran dan Hadis", dalam https://id.123dok.com/document/zlr5v7oz-objek-kajian-living-quran-danhadis.html. Diakses pada 16 Juli 2019.

12 Sudarti Prijono, "Aspek Adaptasi dan Akulturasi Budaya di Situs Bumi Rongsok Tasikmalaya", Purbawidya: Jurnal Penelitian dan Pengembangan Arkeologi, Vol. 4, No. 2 (2015), 2-3.

13 Kodiran, "Akulturasi sebagai Mekanisme Perubahan Kebudayaan", Humaniora, No. 8 (1998), 87.

${ }^{14}$ Umi Sumbulah, "Islam Jawa dan Akulturasi Budaya: Karakteristik, Variasi, dan Ketaatan Ekspresif”, el Harakah, Vol. 14, No. 1 (2012), 57.

15 Subhan MA. Rachman dan Fuad Rahman, "The Dynamic of Malay Islamic Law: The Rise and Practices of Adat Bersendi Syarak, Syarak Bersendi Kitabullah in Jambi," Journal of Indonesian Islam, Vol. 11, No. 2 (2017), 390.
} 
makkiyah maupun ayat madaniyah, yang meliputi jenis pakaian di dunia maupun di akhirat yaitu: (a) pakaian dari api neraka bagi kaum kafir (QS. al-Hajj [22]: 19; (b) pakaian sutra halus yang hijau dan sutra tebal di surga (QS. al-Insān [76]: 21 dan QS. al-Kahf [18]: 31); dan (c) baju (QS. al-Muddaththir [74]: 4, QS. al-Nūr [24]: 58 dan 60, QS. Hūd [11]: 5, dan QS. Nūḥ [71]: 7). ${ }^{16}$ Kedua, terkait dengan kata dasar l-b-s (لبس), Alquran menggunakan empat varian kata dalam 13 belas ayat, baik ayat makkiyah maupun ayat madaniyah, yaitu: (a) talbisūna dalam QS. alNaḥl [16]: 14 dan QS. Fāṭir [35]: 12; (b) yalbasūna dalam QS. al-Kahf [18]: 31 dan QS. al-Dukhān [44]: 53; (c) libās dua kali dalam QS. alBaqarah [2]: 187, dua kali QS. al-A'rāf [7]: 26 dan sekali dalam QS. alA'rāf [7]: 27, QS. al-Naḥl [16]: 112, QS. al-Furqān [25]: 47, QS. alNaba' [78]: 10, QS. al-Hajaj [22]: 23, dan QS. Fātị [35]: 33; dan (d) labūs dalam QS. al-Anbiyä' [21]: $80 .^{17}$

Dalam 13 ayat tersebut, jenis pakaian di dunia dan di akhirat, baik yang berupa pakaian konkret maupun pakaian abstrak, meliputi: (a) pakaian berupa perhiasan dari laut di dunia (QS. al-Naḥl [16]: 14 dan QS. Fātiri [35]: 12); (b) pakaian hijau dari sutra halus dan sutra tebal di surga (QS. al-Kahf [18]: 31, QS. al-Dukhān [44]: 53, QS. al-Ḥajj [22]: 23, dan QS. Fātir [35]: 33); (c) suami dan istri merupakan pakaian bagi pasangannya (QS. al-Baqarah [2]: 187); (d) pakaian sebagai penutup aurat, pakaian indah sebagai perhiasan, dan pakaian ketakwaan (QS. al-A'rāf [7]: 26-27); (e) pakaian kelaparan dan ketakutan (QS. al-Naḥl [16]: 112); (f) malam sebagai pakaian (QS. al-Furqān [25]: 47 dan QS. al-Naba' [78]: 10); dan (g) baju besi (QS. al-Anbiyā' [21]: 80).

Semua ayat di atas, baik yang menggunakan kata dari kata dasar th-y-b (ثيب) maupun kata dasar l-b-s (لبس), tidak menjelaskan secara detail pelbagai jenis pakaian tersebut, baik dari warna, tata cara, konteks, anjuran, perintah, maupun larangannya, terutama pakaian konkret di dunia. Sebagai penjelas Alquran, hadis menjelaskannya. Berdasarkan pelacakan hadis dengan al-Mu'jam al-Mufahras li AlfäzalHadith al-Nabawi, hadis tentang pakaian disebutkan dalam Sabịh alBukbārì, Sahīh Muslim, Sunan Abū Dāwud, Sunan al-Tirmidhì, Sunan alNasā'̄, Sunan Ibn Mājah, Musnad al-Dārimì, Muwaț̣a’ Mälike, dan Musnad

\footnotetext{
16 Muhammad Fu'ād 'Abd al-Bāqī, Al-Mu'jam al-Mufahras li Alfä̀̀ al-Qur'ān al-Karìm (Kairo: Dār al-Hạāìth, 1364 H.), 162.

17 Ibid., 645.
} 
Ahmad ibn Hanbal. Namun, di antara koleksi hadis tentang pakaian itu yang secara khusus terkait dengan hari raya adalah sebagai berikut: ${ }^{18}$

Pertama, al-Bukhārī (194-256 H.) meriwayatkan sebuah hadis dalam Bäb fì al-İdayn wa al-Tajammul fìh di Kitäb al-İdayn dalam Sạ̣ị alBukbāri sebagai berikut: ${ }^{19}$

$$
\begin{aligned}
& \text { حدثنا أبو اليمان قال :أخبرنا شعيب عن الزهري قال :أخبرني سالم بن عبد الله أن عبد }
\end{aligned}
$$

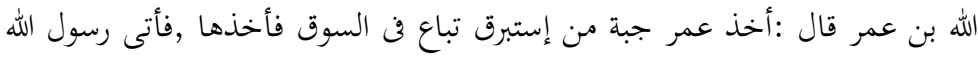

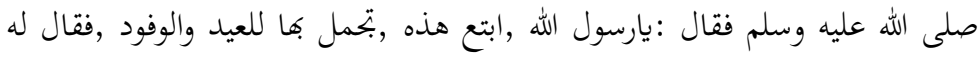

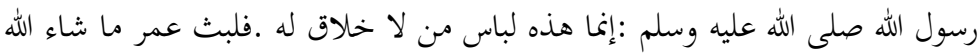

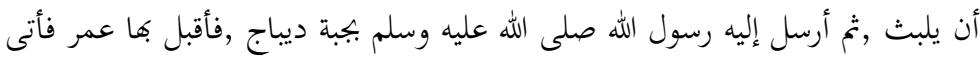

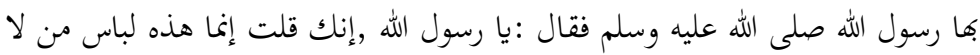

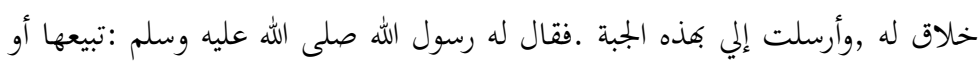

$$
\begin{aligned}
& \text { تصيب بها حاجتك }
\end{aligned}
$$

"Abū al-Yamān meriwayatkan kepada kami, dia berkata, 'Shu'ayb meriwayatkan kepada kami dari al-Zuhrī, dia berkata, 'Sālim b. 'Abd Allāh meriwayatkan kepadaku bahwa 'Abd Allāh b. 'Umar berkata, “"Umar mengambil sebuah jubah dari sutra yang dijual di pasar, lalu dia mendatangi Rasulullah kemudian berkata, 'Wahai Rasulullah, belilah jubah ini dan berhiaslah dengannya untuk hari raya dan menyambut tamu!' Rasulullah pun bersabda kepadanya, 'Sesungguhnya ini hanya pakaian orang yang tidak mendapatkan bagian (di hari kiamat).' 'Umar pun tinggal sepanjang waktu yang Allah kehendaki. Kemudian Rasulullah mengirim jubah sutra kepadanya. 'Umar pun menerimanya lalu dia membawanya kepada Rasulullah. Kemudian dia berkata, 'Wahai Rasulullah, sesungguhnya engkau pernah mengatakan, 'sesungguhnya ini hanya pakaian orang yang tidak mendapatkan bagian (di hari kiamat), dan engkau mengirimkan jubah ini kepadaku.' Lalu Rasulullah bersabda kepadanya, 'Juallah jubah ini atau kamu penuhi kebutuhanmu dengannya!"”

Kedua, Muslim (206-261 H.) meriwayatkan sebuah hadis dengan dua sanad dalam Bäb Tahrìm Isti'mäl Inā' al-Dhahab wa al-Fiddah 'alā alRijäl wa al-Nisà' wa Khatam al-Dhahab wa al-Hẹarir 'alà al-Rijäl wa Ibäḥatih

18 Muhammad Fu'ād 'Abd al-Bāqī, Al-Mu'jam al-Mufahras li Alfä̀े al-Hadìth al-Nabawì (Leiden: Brill, 1936), I/308-312 dan VI/84-85.

19 Al-Bukhārī, Saḥị̄ al-Bukhārī, 231. 
li al-Nisā' wa Ibāhạat al-Tlm wa Naḥwih li al-Rajul mā lam Yarid 'alā Arba' Asābir di Kitāb al-Libās wa al-Zinah dalam Saḥ̄ḥ Muslim sebagai berikut: ${ }^{20}$

$$
\begin{aligned}
& \text { حدثني أبو الطاهر وحرملة بن يهيى واللفظ لحرملة قالا :أخبرنا ابن وهب أخبرخي يونس }
\end{aligned}
$$

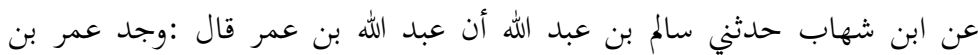

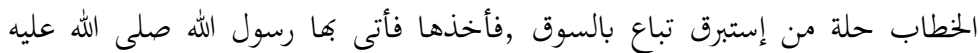



$$
\begin{aligned}
& \text { عليه وسلم :إنما هذه لباس من لا خلاق له .قال فلبث عمر ما شاء الله رثم أرسل إليه }
\end{aligned}
$$

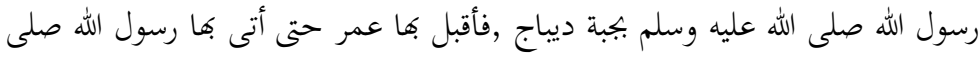

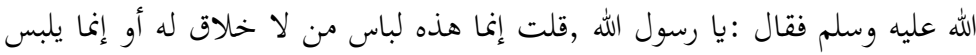



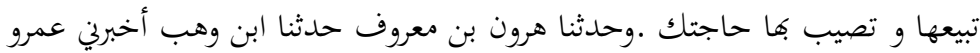

$$
\begin{aligned}
& \text { بن الحارث عن ابن شهاب بهذا الإسناد مثله. }
\end{aligned}
$$

“Abū al-Ṭāhir dan Ḥarmalah b. Yahyā meriwayatkan kepadaku (dan lafaznya milik Harmalah). Mereka berdua berkata, "Ibn Wahb meriwayatkan kepada kami, Yūnus meriwayatkan kepadaku dari Ibn Shihāb, Sālim b. 'Abd Allāh meriwayatkan kepadaku bahwa 'Abd Allāh b. 'Umar berkata, "Umar mendapatkan sebuah jubah dari sutra yang dijual di pasar, lalu dia mengambilnya dan membawanya ke Rasulullah kemudian berkata, 'Wahai Rasulullah, belilah jubah ini dan berhiaslah dengannya untuk hari raya dan menyambut tamu.' Rasulullah pun bersabda kepadanya, 'Sesungguhnya ini hanya pakaian orang yang tidak mendapatkan bagian (di hari kiamat).' 'Umar pun tinggal sepanjang waktu yang Allah kehendaki. Kemudian Rasulullah mengirim jubah sutra kepadanya. 'Umar pun menerimanya hingga dia membawanya kepada Rasulullah. Kemudian dia berkata, 'Wahai Rasulullah, sesungguhnya engkau pernah mengatakan, 'sesungguhnya ini hanya pakaian orang yang tidak mendapatkan bagian (di hari kiamat),' atau 'sesungguhnya orang yang memakai pakaian ini adalah orang yang tidak mendapatkan bagian (di hari kiamat)', lalu engkau mengirimkan jubah ini kepadaku?' Lalu Rasulullah bersabda kepadanya, Juallah jubah ini atau kamu penuhi kebutuhanmu dengannya!' Harūn b. Ma'rūf meriwayatkan kepada

${ }^{20}$ Al-Naysābūrī, Saḥị̣ Muslim, 1146. 
kami, Ibn Wahb meriwayatkan kepada kami, 'Amrū b. al- Hāarith meriwayatkan kepadaku dari Ibn Shihāb dengan sanad seperti ini."

Ketiga, al-Nasā'̄ (215-303 H.) meriwayatkan sebuah hadis dalam

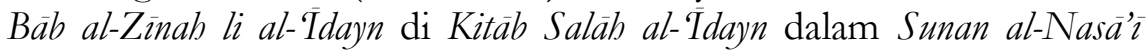
sebagai berikut: ${ }^{21}$

$$
\begin{aligned}
& \text { أخبرنا سليمان بن داود عن ابن وهب قال :أخبرني يونس بن يزيد و عمرو بن الحارث } \\
& \text { عن ابن شهاب عن سالم عن أبيه قال :وجد عمر بن الخطاب رضي الله عنه حلة من } \\
& \text { إستبرق تباع بالسوق ,فأخذها فأتى بها رسول الله صلى الله عليه وسلم قال :رسول الله } \\
& \text { صلى الله عليه وسلم ,ابتع هذه ,فتجمل بها للعيد وللوفد ,فقال رسول الله صلى الله } \\
& \text { عليه وسلم :إنما هذه لباس من لا خلاق له أو إنما يلبس هذه من لا خلاق له .فلبث } \\
& \text { عمر ما شاء الله ,ثم أرسل إليه رسول الله صلى الله عليه وسلم بجبة ديباج ,فأقبل .ها } \\
& \text { حتى جاء رسول الله صلى الله عليه وسلم فقال :يا رسول الله ,قلت إنما هذه لباس من } \\
& \text { لا خلاق له ,ثم أرسلت إلي هذذه؟ فقال رسول الله صلى الله عليه وسلم :بعها و تصب } \\
& \text { بها حاجتك. }
\end{aligned}
$$

"Sulaymān b. Dāwud meriwayatkan kepada kami dari Ibn Wahb. Dia berkata, "Yūnus b. Yazīd dan 'Amrū b. al-Ḥārith meriwayatkan kepadaku dari Ibn Shihāb dari Sālim dari bapaknya. Dia berkata, "Umar b. al-Khațāa mendapatkan sebuah jubah dari sutra yang dijual di pasar, lalu dia mengambilnya dan membawanya ke Rasulullah. Dia berkata, Wahai Rasulullah, belilah jubah ini dan berhiaslah dengannya untuk hari raya dan menyambut tamu.' Rasulullah pun bersabda, 'Sesungguhnya ini hanya pakaian orang yang tidak mendapatkan bagian (di hari kiamat)' atau 'sesungguhnya orang yang memakai pakaian ini adalah orang yang tidak mendapatkan bagian (di hari kiamat).' 'Umar pun tinggal sepanjang waktu yang Allah kehendaki. Kemudian Rasulullah mengirim jubah sutra kepadanya. 'Umar pun menerimanya hingga dia mendatangi Rasulullah. Kemudian dia berkata, Wahai Rasulullah, sesungguhnya engkau pernah mengatakan, 'sesungguhnya ini hanya pakaian orang yang tidak mendapatkan bagian (di hari kiamat),' lalu engkau mengirimkan jubah ini kepadaku?' Lalu Rasulullah saw. bersabda kepadanya, 'Juallah jubah ini atau kamu penuhi kebutuhanmu dengannya!"'

${ }^{21}$ Abū 'Abd al-Raḥmān Aḥmad b. Shu'ayb b. 'Alī al-Nasā'̄', Sunan al-Nasā't (Riyad: Maktabah al-Ma'ārif, t.th.), 257. 
Tiga hadis ini memiliki empat sanad. Pertama, al-Bukhārī $\rightarrow$ Abū al-Yamān $\rightarrow$ Shu'ayb $\rightarrow$ al-Zuhrī $\rightarrow$ Sālim b. 'Abd Allāh $\rightarrow$ 'Abd Allāh b. 'Umar. Kedua, Muslim $\rightarrow$ Abū al-Ṭāhir dan Harmalah b. Yaḥyā $\rightarrow$ Ibn Wahb $\rightarrow$ Yūnus $\rightarrow$ Ibn Shihāb $\rightarrow$ Sālim b. 'Abd Allāh $\rightarrow$ 'Abd Allāh b. 'Umar. Ketiga, Muslim $\rightarrow$ Harūn b. Ma'rūf $\rightarrow$ Ibn Wahb $\rightarrow$ 'Amrū b. alḤārith $\rightarrow$ Ibn Shihāb $\rightarrow$ Sālim b. 'Abd Allāh $\rightarrow$ 'Abd Allāh b. 'Umar. Keempat, al-Nasā̄i $\rightarrow$ Sulaymān b. Dāwud $\rightarrow$ Ibn Wahb $\rightarrow$ Yūnus b. Yazīd dan 'Amrū b. al-Hāàith $\rightarrow$ Ibn Shihāb $\rightarrow$ Sālim $\rightarrow$ 'Abd Allāh b. 'Umar. Skema empat sanad ini adalah sebagai berikut:

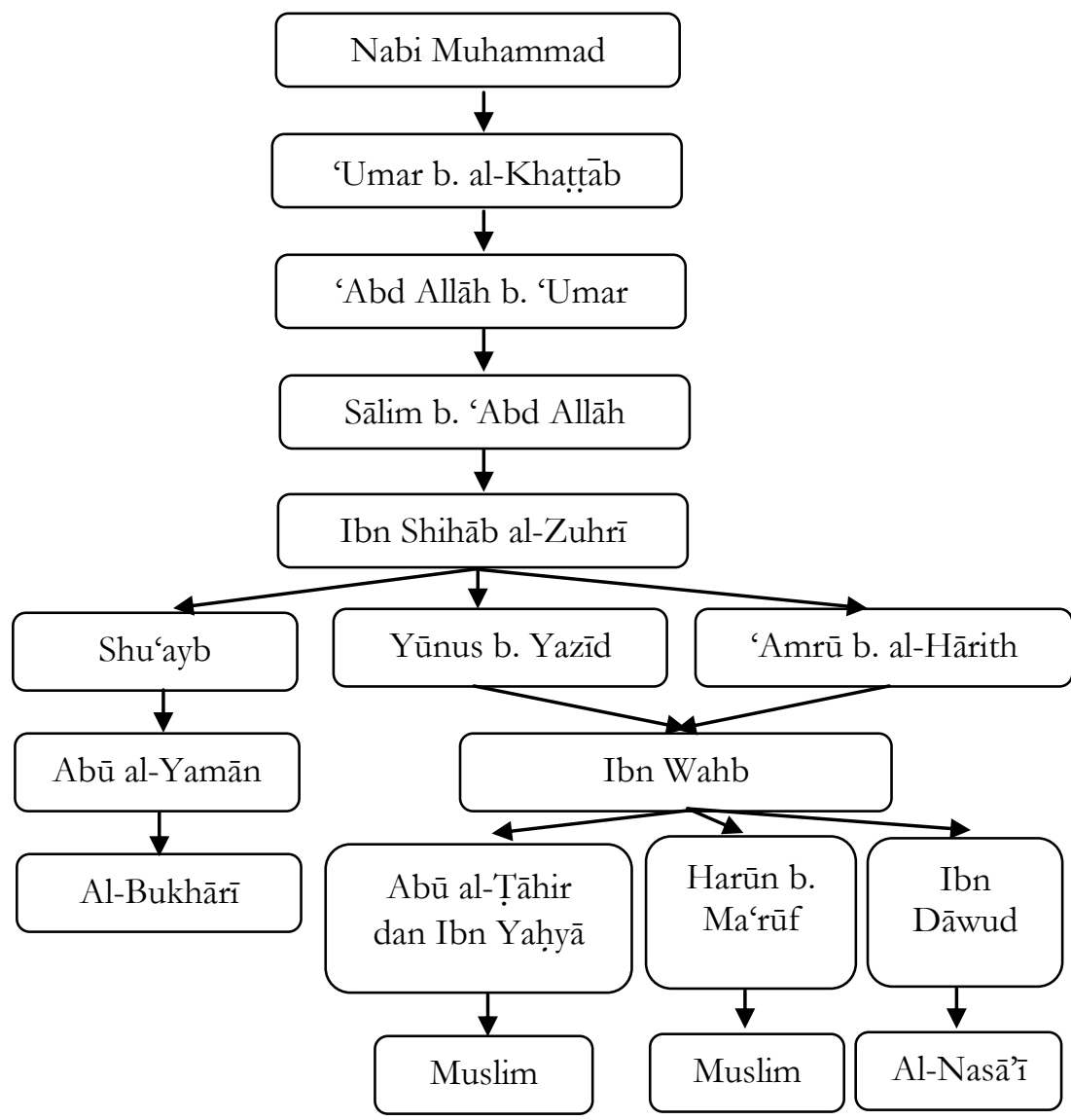

Tabel 1. Skema Sanad Hadis Pakaian Baru pada Hari Raya 
Skema empat sanad di atas menunjukkan bahwa semua hadis tersebut berasal dari 'Abd Allāh b. 'Umar sebagai periwayat pertama yang menyaksikan sabda dan perbuatan Rasulullah dengan bapaknya, yaitu 'Umar b. al-Khattāb. Hadis ini merupakan ḅadith qawlì dan hadith 'amali. Dari Ibn 'Umar hadis ini kemudian ditransmisikan ke putranya, yaitu Sālim b. 'Abd Allāh. Hadis ini melibatkan kakek, anak, dan cucu. Dari Sālim b. 'Abd Allāh hadis ini kemudian ditransmisikan ke muridnya, yaitu Ibn Shihāb al-Zuhrī. Sanad hadis ini dari Rasulullah hingga al-Zuhrī merupakan sanad dengan jalur tunggal. Dari al-Zuhrī hadis ini kemudian menyebar ke tiga periwayat, yaitu Shu'ayb, Yūnus b. Yazīd, dan 'Amrū b. al-Ḥārith yang kemudian menyebar ke para periwayat lain hingga ke mukharrijün (para perawi sekaligus penulis kitab hadis) sebagai berikut: pertama, dari jalur Shu'ayb hadis ini kemudian ditransmisikan ke Abū al-Yamān lalu terakhir ke al-Bukhārī sebagai mukharrij. Kedua, dari jalur Yūnus b. Yazīd hadis ini kemudian ditransmisikan ke Ibn Wahb lalu ke dua orang periwayat yaitu Abū alṬāhir dan Harmalah b. Yahyā lalu terakhir ke Muslim sebagai mukharrij. Ketiga, dari jalur 'Amrū b. al-Hārith hadis ini kemudian ditransmisikan ke Ibn Wahb lalu ke Harūn b. Ma'rūf lalu terakhir ke Muslim sebagai mukharrij. Keempat, dari jalur 'Amrū b. al-Hārith dan Yūnus b. Yazīd hadis ini kemudian ditransmisikan ke Ibn Wahb lalu ke Sulaymān b. Dāwud lalu terakhir ke al-Nasā̄ī sebagai mukharrij.

Kualitas tiga hadis ini adalah sahih, karena dua hadis di antaranya diriwayatkan oleh al-Bukhārī dan Muslim dalam kitab Sahīh mereka, sehingga kesahihannya telah diakui oleh mayoritas umat Islam di kalangan Suni. Sedangkan satu hadis yang diriwayatkan oleh al-Nasā̄̄ dinilai sebagai hadis sahih muttafaq 'alayh oleh 'Alī b. Ādam b. Mūsā alWallawīi dan Muhammad Nāsir al-Dīn al-Albānī (1914-1999 M.), ${ }^{23}$ sehingga dianggap telah memenuhi unsur kesahihan hadis dari dua kritikus hadis hingga ada pembuktian terbaliknya dari kritikus hadis lain. Apalagi tiga hadis ini saling menguatkan satu sama lain, baik dari segi kemiripan matan yang diriwayatkan secara maknawi (al-riwāyah bi al-ma'na) maupun dari segi sanadnya.

Dalam al-Minhāj, Yahyā b. Sharaf al-Nawawī (631-676 H.) mengutip pendapat ahli bahasa bahwa kata bullah dalam hadis di atas hanya menunjukkan dua pakaian yang biasanya berupa sarung (kain

22 'Alī b. Ādam b. Mūsā al-Atyūbī al-Wallawī, Dhakhìrah al-'Uqbā fì Sharḥ al-Mujtabā, Vol. XVII (Mekah: Dār Āl Barūm, 2003), 160.

${ }^{23}$ Ibid. 
pinggang) dan ridä' (pakaian). Menurutnya, hukum memakai pakaian paling bagus pada hari Jumat, hari raya, menyambut tamu, dan hari atau momentum lainnya adalah diajurkan (mustabab). ${ }^{24}$ Tradisi memakai pakaian terbaik pada momen tertentu telah dipraktikkan sejak masa awal Islam. Di antara para sahabat Nabi yang menggunakan pakaian terbaiknya pada saat Idulfitri dan Iduladha adalah 'Abd Allāh b. 'Umar.

Hal ini berdasarkan keterangan Ibn Hajar al-'Asqalānī (773-852 H.), komentator Sahịh al-Bukhārì terkemuka. Dalam Fatḥ al-Bārì, meski tidak menjelaskan hadis riwayat al-Bukhārī tersebut dalam kitāb 'idayn, al-'Asqalānī secara sekilas menjelaskan faidah hadis ini, yaitu Ibn 'Abī al-Dunyā dan al-Bayhaqī meriwayatkan dengan sanad yang sahih bahwa Ibn 'Umar, yang merupakan perawi utama hadis ini, memakai pakaian terbaiknya pada saat Idulfitri dan Iduladha. ${ }^{25}$ Al-'Asqalānī menjelaskan hadis ini pada kitāb al-libās bahwa 'Umar b. al-Khattāb melihat 'Uțārid al-Taymī, yaitu Ibn Hājib Zurārah b. 'Udus, menjual jubah di pasar. Dia merupakan seseorang dari Bani Tamim yang membuatkan baju bagi para penguasa dan mengambil keuntungan dari mereka. Dia pernah membawa jubah sutra yang dipakai oleh kisra. Dia lalu memeluk agama Islam. Rasulullah kemudian mempekerjakannya untuk mengurus sedekah kaumnya. Oleh karena itu, 'Umar menawarkan untuk membelikan jubah sutra untuk beliau agar beliau memakainya pada saat menyambut tamu, berkhutbah saat hari raya, dan momen lain ${ }^{26}$ yang tidak disebutkan secara jelas dalam sumber ini.

Muhạmmad b. 'Abd al-Hādī al-Sindī (w. 1138 H.), seorang ulama hadis yang hidup setelah al-Nawawī dan al-'Asqalānī, juga menegaskan bahwa berhias pada hari raya merupakan tradisi yang telah dikenal di antara orang Arab dan Nabi tidak mengingkarinya, sehingga eksistensi tradisi itu dimaklumi bersama. Penegasannya dituangkan dalam Hāshìyat al-Sind̄̄ saat mengomentari hadis riwayat al-Nasā'̄ dalam Sunan al-Nasā' $\mathrm{di}$ atas, ${ }^{27}$ yang kemudian disepakati oleh 'Alī b. Ādam

24 Al-Nawawī, Saḥị Muslim bi Sharḅ al-Nawawī, Vol. XIV (Kairo: al-Matba'ah alMisrīyah bi al-Azhar, 1929), 38.

25 Aḥmad b. 'Alī b. Hajar al-'Asqalānī, Fatḥ al-Bārì bi Sharḥ Saḥ̄ḥ al-Bukhārì, Vol. II (Beirut: Dār al-Ma'rifah, t.th.), 439.

26 Ibid., Vol. X, 298.

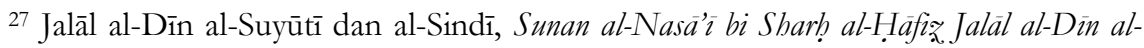
Suyūịi wa Hậshìyat al-Imām al-Sindì (Beirut: Dār al-Ma'rifah, t.th.), 200-201. 
b. Mūsā al-Wallawī dalam Dhakhirah al-Uqaā fí Sharh al-Mujtabä. ${ }^{28}$ Selain itu, menurut al-Wallawī, ulama menganjurkan untuk berhias dalam seluruh forum kebaikan, kecuali dalam forum yang sebaiknya menunjukkan perasaan miskin, tawaduk, dan takut seperti saat salat istiska dan salat kusuf. ${ }^{29}$ Menurut al-Ṭāhir b. 'Āshūr (1296-1393 H.), tindakan memakai pakaian yang terbaik pada hari raya Idulfitri termasuk ekspresi rasa syukur. ${ }^{30}$

\section{Pandangan Orang Madura tentang Tradisi Pakaian Baru pada Hari Raya}

Untuk mengetahui pandangan orang Madura tentang tradisi pakaian baru pada hari raya, penelitian ini menggunakan kuesioner yang dibagikan ke responden, baik laki-laki maupun perempuan, menjelang hari raya Idulfitri tentang empat hal, yaitu: (a) kebiasaan memakai pakaian baru pada hari raya; (b) makna di balik tradisi memakai pakaian baru pada hari raya; (c) dalil agama di balik tradisi memakai pakaian baru; dan (d) tradisi memakai pakaian baru pada hari raya di Madura. Jumlah total responden adalah sebanyak 239 orang. Mereka berasal dari empat kabupaten di Madura, yaitu satu orang dari Bangkalan, 25 orang dari Sampang, 177 orang dari Pamekasan, dan 36 orang dari Sumenep. Jawaban mereka atas empat pertanyaan dalam kuesioner tersebut adalah sebagai berikut:

Pertama, terkait dengan kebiasaan memakai pakaian baru pada hari raya, dari 239 responden, 163 atau 68,20\% responden menyatakan selalu memakai pakaian baru pada hari raya, sedangkan 76 atau $31,79 \%$ responden menyatakan hanya kadang-kadang memakainya.

Di antara alasan responden yang menyatakan selalu memakai pakaian baru pada hari raya adalah karena tradisi ini merupakan kebiasaan sejak kecil. Hal ini diungkapkan oleh Rika Wahyuni, warga Dasuk, Sumenep. ${ }^{31}$ Dena Mellia, Pademawu, Pamekasan, mengungkapkan alasan lain di balik kebiasaannya selalu memakai pakain baru pada hari raya, yaitu bentuk syukur karena telah selesai melaksanakan ibadah puasa sebulan penuh, dan merupakan suatu

\footnotetext{
28 Al-Wallawī, Dhakhìrah al- 'Uqbā, Vol. XVII, 160.

${ }^{29}$ Ibid., Vol. XVI, 146.

30 Muḥammad al-Ṭāhir b. 'Āshūr, Al-Taḥrì wa al-Tanwìr, Vol. 2 (Tunisia: al-Dār alTūnisiyah li al-Nashr, 1984), 177.

${ }^{31}$ Diolah dari hasil kuesioner dari Rika Wahyuni, Sumenep, Senin, 13 Mei 2019.
} 
kesenangan bagi setiap umat Islam. ${ }^{32}$ Selain memakai pakaian baru pada hari raya dianggap sebagai tradisi, Zahrotul Hasanah, warga Pasongsongan, Sumenep, mengaitkan tradisi ini dengan tradisi tunangan di Madura. Menurutnya, dalam tradisi masyarakat Pasongsongan, Sumenep, calon suami memberikan baju baru (baju lebaran) kepada tunangannya untuk dipakai saat lebaran. ${ }^{33} \mathrm{Di}$ sisi berseberangan, di antara alasan responden yang menyatakan hanya kadang-kadang memakai pakaian baru pada hari raya adalah alasan ekonomi, usia, dan pola pikir. Misalnya adalah Siti Nor Komariyah, warga Pademawu, Pamekasan, yang menyatakan bahwa selama hari raya dia tidak pernah dibelikan pakaian baru oleh orang tuanya. Dia baru bisa memakai pakaian baru saat punya uang sendiri. ${ }^{34}$ Berbeda dengan Komariyah, Annisa Salwa Maulina, warga Jalan Stadion, Pamekasan, menyatakan bahwa baju baru merupakan sebuah kewajiban saat lebaran baginya saat dia masih kecil hingga SMP (Sekolah Menengah Pertama), tetapi setelah mengenyam bangku SMA (Sekolah Menengah Atas) dia mulai menyadari bahwa baju baru tidak penting, karena dia merasa umurnya semakin tua dan memiliki adik yang senang diberi baju baru, apalagi pemberiannya tepat di hari lebaran. ${ }^{35}$

Kedua, terkait dengan makna di balik tradisi memakai pakaian baru pada hari raya, jawaban responden beragam, yaitu: (a) untuk menghormati datangnya bulan suci; (b) budaya atau tradisi; (c) tidak bermakna apa pun, karena yang paling bermakna adalah berkumpul dengan keluarga lengkap dalam keadaan sehat walafiat, karena pakaian baru tidak menjamin kebahagiaan; (d) bentuk partisipasi, syukur, dan antusiasme atas penyambutan dan perayaan Idulfitri sebagai hari besar, sehingga tanpa pakaian baru seperti tidak berlebaran; (e) simbol hari raya; ( $\mathrm{f}$ ) hadiah atas puasa yang dilakukan; ( $\mathrm{g}$ ) pakaian baru sebagai pelengkap; dipakai jika ada dan jika tidak ada tidak masalah; (h) simbol kesucian jati diri untuk fitrah manusia yang masih suci dan baru ; (i) hari baru, jiwa baru, dan baju baru; (j) kepuasan, kesenangan

\footnotetext{
32 Diolah dari hasil kuesioner dari Dena Mellia, Pamekasan, pada hari Selasa, 14 Mei 2019.

33 Diolah dari hasil kuesioner dari Zahrotul Hasanah, Sumenep, pada hari Senin, 13 Mei 2019.

34 Diolah dari hasil kuesioner dari Siti Nor Komariyah, Pamekasan, pada hari Senin, 13 Mei 2019.

35 Diolah dari hasil kuesioner dari Annisa Salwa Maulina, Pamekasan, pada hari Selasa, 14 Mei 2019.
} 
atau kebahagiaan; (k) kepuasan karena sudah berpuasa selama sebulan; (l) supaya tampil cantik dan menarik; (m) ria atau pamer pakaian barunya; (n) lambang kemenangan melawan hawa nafsu; (o) anjuran; (p) tampil beda, percaya diri, dan keren; (q) membuka lembar baru dalam penutupan bulan suci Ramadan dengan alasan memiliki hati baru yang lebih baik dari sebelumnya; (r) ingin sama dengan orang lain dan tidak dikucilkan oleh tetangga; (s); agar terlihat berbeda dengan hari-hari sebelumnya; $(t)$ pada hari yang fitri harus dalam keadaan suci ketika berada di rumah Allah dengan tujuan agar terhindar dari najis dan tetap suci di hadapan Allah; (u) lambang kecintaan terhadap bulan Ramadan; dan (v) tidak mengetahui maknanya.

Di antara alasan responden yang menyatakan bahwa tradisi ini sebagai ungkapan syukur kepada Allah adalah Ali Makki, warga Sokobanah, Sampang. ${ }^{36}$ Ungkapan syukur ini identik dengan perayaan hari besar Islam, sebagaimana diungkapkan oleh Desi Kurniawati Ningsih, warga Bluto, Sumenep bahwa makna dari pakaian baru adalah bukti atas keinginan untuk merayakan hari besar Islam, selain bersyukur atas nikmat-Nya. ${ }^{37}$ Selain sebagai ungkapan syukur, Diana Eka, warga Toronan, Pamekasan, menilainya sebagai apresiasi orang tua kepada anaknya yang berpuasa, terutama yang masih di bawah umur, sehingga hal tersebut akan memicu semangatnya. Namun, hal tersebut juga bisa mengakibatkan pola pikir yang kurang baik terhadap anak; ia akan berpikir bahwa dia harus menggunakan pakaian baru pada hari raya. ${ }^{38}$ Di sisi berseberangan, sebagian responden mengganggap tradisi ini tidak bermakna apa pun, bahkan ia hanya merupakan ajang pamer kemewahan. Anggapan ini di antaranya diungkapkan oleh Miga, warga Robatal, Sampang. ${ }^{39}$

Ketiga, terkait dengan dalil agama di balik tradisi memakai pakaian baru pada hari raya, dari 239 responden, sebanyak 20 atau $8,36 \%$ responden menyatakan ada dalilnya, sebanyak 122 atau 51,04\% responden menjawab tidak tahu, dan sebanyak 97 atau 40,58\% responden menyatakan tidak ada dalilnya.

\footnotetext{
36 Diolah dari hasil kuesioner dari Ali Makki, Sampang, pada hari Jumat, 17 Mei 2019.

37 Diolah dari hasil kuesioner dari Desi Kurniawati Ningsih, Sumenep, pada hari Selasa, 14 Mei 2019.

${ }^{38}$ Diolah dari hasil kuesioner dari Diana Eka, Pamekasan, pada hari Senin, 13 Mei 2019.

${ }^{39}$ Diolah dari hasil kuesioner dari Miga, Sampang, pada hari Jumat, 17 Mei 2019.
} 
Qorinatul Jamilah, warga Bluto, Sumenep, adalah seorang responden dari 97 atau 40,58\% responden yang menyatakan tidak ada dalil di balik tradisi ini, yaitu tidak ada anjuran dalam agama Islam atau dalil, baik dalam Alquran maupun hadis, sehingga tradisi mengenakan pakaian baru di Madura hanya inisiatif dari masyarakat dan telah menjadi tradisi yang harus dilaksanakan. Namun, tradisi ini tergantung pada kemampuan atau ketidakmampuan seseorang untuk membeli pakaian baru, sehingga dia tidak memaksakan kehendak berlebihan yang bisa menimbulkan perbuatan negatif. Jadi, orang yang memiliki kemampuan secara materi boleh mengikuti tradisi ini, tetapi harus disesuaikan dengan kadar kebutuhan dan tidak berlebihan. ${ }^{40}$ Di sisi lain, Ali Makki, warga Sokobanah, Sampang, menyatakan tradisi ini berdasarkan dalil, yaitu "yawm yusann fìh labs al-libās al-jadìd." Sayangnya, Makki tidak menyebutkan asal-muasal dalil ini, sehingga keberadaannya tidak bisa dilacak secara pasti. Padahal hanya dia yang secara eksplisit menyebutkan ada dalil di balik tradisi ini dari 20 atau $8,36 \%$ responden yang menyatakan pendapat serupa.

Keempat, terkait dengan pandangan tentang tradisi memakai pakaian baru pada hari raya berdasarkan pengalaman, pengetahuan, dan pengamatan langsung tentang tradisi memakai pakaian baru pada hari raya di Madura, pandangan mereka beragam, yaitu: (i) biasa-biasa saja sebagai wujud kebahagiaan dan kegembiraan; (ii) budaya, tradisi atau simbol hari raya secara turun-temurun yang tidak hanya terjadi di Madura dan sulit dihilangkan; (iii) kewajaran sebagai kebahagiaan setiap orang saat memakai sesuatu yang baru; (iv) hanya mengikuti perkembangan zaman dan mungkin ada yang berlomba-lomba membeli pakaian baru untuk memperlihatkan baju barunya; (v) membeli pakaian baru selama masih ada pakaian yang layak pakai adalah pemborosan; (vi) tidak setuju dengan tradisi ini karena secara tidak langsung mendorong masyarakat untuk berlomba-lomba dalam membeli dan memamerkan bajunya yang baru serta mahal, bukan mendorong untuk meningkatkan silaurahmi terhadap sesama; (v) sebagai wujud penghormatan dan syukur karena bulan Ramadan telah berlalu; (vi) kewajiban; (vii) tradisi memakai pakaian baru pada hari raya sangat sakral dan membawa dampak positif karena

\footnotetext{
${ }^{40}$ Diolah dari hasil kuesioner dari Qorinatul Jamilah, Sumenep, pada hari Selasa, 14 Mei 2019.

${ }^{41}$ Diolah dari hasil kuesioner dari Ali Makki, Sampang, pada hari Jumat, 17 Mei 2019.
} 
menumbuhkan semangat dalam ikut lebaran; (viii) penyempurna lebaran, karena lebaran terasa kurang lengkap tanpa pakaian baru; (ix) tradisi memakai pakaian baru pada hari raya adalah tradisi bagus sebagai perayaan hari besar Islam, tetapi tidak boleh berlebihan, karena yang dicari di hari itu adalah keberkahan, bukan pakaian baru; dan (x) untuk membahagiakan keluarganya, terutama anak-anak.

Di antara responden ada yang menyatakan bahwa mayoritas masyarakat Madura menyalahartikan tradisi ini untuk kesombongan, sebagaimana diungkapkan oleh Wardatul Faihah, warga Klapayan, Sepulu, Bangkalan. Menurutnya, mayoritas masyarakat Madura hanya menyombongkan diri dengan menunjukkan bahwa ia mampu membeli tanpa mengetahui makna yang sebenarnya. Perilaku ini bukan karena untuk mendapatkan pahala. Mereka tidak menyadari bahwa masih banyak orang yang tidak bisa membeli atau memakai pakaian baru. Seharusnya, pakaian bukan merupakan titik ukur ketakwaan kepada Allah. ${ }^{42}$ Pendapat senada diungkapkan oleh Hoirul Jakfar Sodik, warga Pangilen, Sampang, bahwa tradisi ini hanya mengikuti perkembangan zaman. Mungkin ada orang yang berlombalomba membeli pakaian baru untuk memperlihatkannya. ${ }^{43}$ Penilaian moderat tentang tradisi ini diungkapkan oleh Dandy Septian Pratama, warga Gladak Anyar, Pamekasan. Menurutnya, tradisi ini sah-sah saja asalkan tidak melenceng dari syariat Islam, yaitu tidak ada kepercayaan lain dari pemakaian pakaian baru, sehingga orang yang belum mampu membelinya tidak perlu memaksakan diri karena masih ada baju lama yang layak dipakai pada hari raya. ${ }^{44}$ Pernyataan serupa diungkapkan oleh Ulfa Anisa, warga Batang-Batang, Sumenep, bahwa tradisi ini merupakan tradisi baik, karena menampakkan kebahagiaan dan wujud syukur atas nikmat Allah. Selain itu, tradisi ini merupakan ekspresi kebahagiaan menyambut hari raya dengan syarat tidak memaksakan diri untuk mendapatkannya, seperti mencuri, berutang, dan segala bentuk perbuatan buruk lainnya. ${ }^{45}$

42 Diolah dari hasil kuesioner dari Wardatul Faihah, Bangkalan, pada hari Senin, 13 Mei 2019.

43 Diolah dari hasil kuesioner dari Hoirul Jakfar Sodik, Sampang, pada hari Selasa, 14 Mei 2019.

44 Diolah dari hasil kuesioner dari Dandy Septian Pratama, Pamekasan, pada hari Senin, 13 Mei 2019.

45 Diolah dari hasil kuesioner dari Ulfa Anisa, Sumenep, pada hari Jumat, 17 Mei 2019. 


\section{Identifikasi dan Urgensi Tradisi Pakaian Baru pada Hari Raya di Madura sebagai Living Hadith}

Berdasarkan jawaban 239 responden dari berbagai daerah di Madura dalam kuesioner, pandangan masyarakat Madura tentang tradisi pakaian baru pada hari raya di Madura beragam, baik dari segi kuantitas pemakaian, pemaknaan, relasi tradisi ini dengan ajaran Islam, maupun pendapat mereka tentang tradisi ini di Madura berdasarkan pengalaman, pengetahuan, dan pengamatan mereka. Mayoritas responden menyatakan tradisi ini hanya tradisi biasa yang dilakukan secara turun-temurun dan tidak terkait langsung dengan ajaran Islam, sehingga bisa dilestarikan atau tidak karena mengandung unsur positif dan unsur negatif.

Unsur positif dalam tradisi ini mencakup penghormatan, rasa syukur, kegembiraan, kepuasaan dalam menyambut hari raya, karena mereka telah melawan hawa nafsu dan berpuasa selama bulan Ramadan. Selain itu, tradisi ini juga bisa meningkatkan geliat perekonomian dan keharmonisan rumah tangga, karena mayoritas masyarakat Madura memakai pakaian baru pada hari raya dengan cara membeli dan sebagian menghadiahkannya kepada anak-anak mereka. Di sisi lain, unsur negatif tradisi ini adalah pemborosan dan pamer, sehingga terkesan ada unsur pemaksaan diri agar terlihat keren, mampu membeli pakaian baru, dan bahkan berlomba-lomba sebagai pemilik pakaian baru yang terbaik, padahal sebagian masyarakat Madura secara ekonomi tergolong tidak mampu.

Pernyataan mayoritas responden bahwa tradisi memakai pakaian baru pada hari raya hanya tradisi biasa semakin dikuatkan oleh ketidaktahuan mereka tentang asal-muasal tradisi ini. Dari 239 responden, sebanyak 28 responden menyatakan bahwa Islam menganjurkannya, sebanyak enam responden menyatakan bahwa memakai pakaian baru hanya dianjurkan bagi yang mampu, sebanyak 36 responden yang menyatakan tidak tahu bahwa Islam menganjurkan, dan 169 responden menyatakan bahwa Islam tidak menganjurkan. Angka ini menunjukkan bahwa mayoritas mereka tidak menyadari bahwa tradisi ini sebenarnya bersumber dari ajaran Islam. Bahkan ketika mereka ditanya lebih detail tentang dalil agama di balik tradisi ini, dari 239 responden tersebut, sebanyak 20 responden menyatakan ada dalil agama di balik tradisi ini, sebanyak 122 responden menjawab tidak tahu tentang dalil agama di balik tradisi ini, 
dan sebanyak 97 responden menyatakan tidak ada dalil agama di balik tradisi ini.

Ironisnya, dari 20 responden yang menyatakan ada dalil agama di balik tradisi ini, tidak ada satu pun yang secara tepat menyebutkan dalil agama yang dimaksud, karena sebagian hanya pernah mendengar dan membaca tetapi lupa, sebagian lagi mengetahuinya dari lagu, dan sebagian lagi menyebutkan dalil agama tetapi tidak sempurna, yaitu: "Allah menyukai keindahan", "yawm yusannu fìh labs al-libās al-jadìd," dan "labs al-jadid". Dalil "Allah menyukai keindahan" memang merupakan hadis sahih yang diriwayatkan oleh Muslim, ${ }^{46}$ tetapi dalil ini masih bersifat umum yang mencakup semua perintah Allah dan perbuatan baik. ${ }^{47}$ Sedangkan dalil kedua dan ketiga lebih identik dengan pendapat fukaha dalam memahami hadis daripada sebuah hadis itu sendiri, karena redaksi ini belum ditemukan dalam kitabkitab induk hadis melalui takhrij al-hadith yang dilakukan.

Fakta ini semakin menunjukkan bahwa mayoritas mereka tidak mengetahui secara pasti sumber tradisi ini. Padahal mayoritas mereka mempraktikkannya setiap tahun. Meski demikian, poin penting dari data itu menunjukkan bahwa ungkapan-ungkapan yang mereka anggap sebagai dalil bukan merupakan ayat Alquran. Hal ini mengindikasikan bahwa mereka mengetahui tradisi ini dari luar Alquran. Apalagi sebagian responden menyatakan bahwa tradisi ini bersumber dari hadis, meski mereka tidak bisa menyebutkannya secara detail.

Berdasarkan aspek sosial-keagamaannya, mayoritas masyarakat dipengaruhi oleh ajaran Islam secara signifikan, baik dari segi pakaian maupun perilaku. Namun mereka tidak menyadari bahwa sebagian tradisi di lingkungan mereka sebenarnya bersumber dari Islam, sehingga mereka menganggapnya hanya tradisi biasa yang diwariskan secara turun-temurun dari nenek moyang mereka. Sebagian dari tradisi tersebut adalah memakai pakaian baru pada hari raya, yang esensinya secara jelas menunjukkan pengaruh ajaran Islam, yang kemudian dianggap hanya tradisi biasa karena sudah mengakar kuat di kalangan mereka, baik di komunitas santri, priayi, maupun abangan.

Tiga hadis sahih dari 'Abd Allah b. 'Umar yang diriwayatkan al-

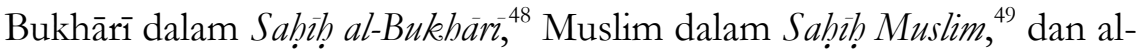

46 Al-Naysābūrī, Saḅ̄ḥ Muslim, 60-61.

${ }^{47}$ Al-Nawawī, Sharb al-Nawawi, Vol. II, 89-92.

48 Al-Bukhārī, Saḥ̣̄̄ al-Bukhārì, 231. 
Nasā'̄ dalam Sunan al-Nasâ', memakai pakaian terbaiknya saat Idulfitri dan Iduladha, ${ }^{51}$ pemahaman al-Bukhārī tentang hadis Ibn 'Umar yang meletakkan hadisnya dalam

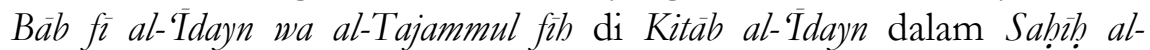
Bukhārì, pemahaman al-Nasā̄̄ tentang hadis Ibn 'Umar yang meletakkan hadisnya dalam Bäb al-Zinah li al-'Tdayn di Kitäb Saläh al$\bar{T}$ dayn dalam Sunan al-Nasă, $\bar{\imath}$, dan pendapat al-Nawawi tentang anjuran memakai pakaian paling bagus pada hari Jumat, hari raya, menyambut tamu, dan momentum lainnya ${ }^{54}$ menunjukkan bahwa tradisi memakai pakaian baru pada hari raya bersumber dari hadis sahih.

Penting dicatat, tiga hadis tersebut memang tidak secara eksplisit menyebutkan "pakaian baru", bahkan Ibn 'Umar hanya memakai "pakaian terbaik", bukan "pakaian baru", tetapi secara implisit tiga hadis tersebut menunjukkan "pakaian baru", karena biasanya orang membeli sesuatu yang baru di pasar sebagaimana konteks tiga hadis tersebut. Apalagi tiga hadis tersebut menyebutkan pakaian sutra, seperti hadis riwayat al-Bukhārī yang menyebut "jubbah min istabraq" (jubah dari sutra) ${ }^{55}$ serta hadis riwayat Muslim ${ }^{56}$ dan al-Nasāân menyebut "bullah min istabraq" (jubah dari sutra). Biasanya, pakaian sutra hanya dijual dalam kondisi baru. Selain itu, pakaian terbaik lebih identik dengan pakaian baru, meski tidak selamanya. Dengan demikian, berdasarkan pandangan Clifford Geertz (1926-2006) bahwa penerimaan otoritas atas ritual keagamaan bermula sejak ritual itu mulai dipraktikkan, ${ }^{58}$ tradisi memakai pakaian baru pada hari raya merupakan living hadith, karena keberadaannya diinspirasi dan diperkuat oleh hadis.

Sejauh ini, belum ada penelitian yang menunjukkan asal-mula tradisi ini diresepsi oleh masyarakat Madura. Namun, hal ini tidak menafikan bahwa tradisi ini merupakan living hadith, karena proses

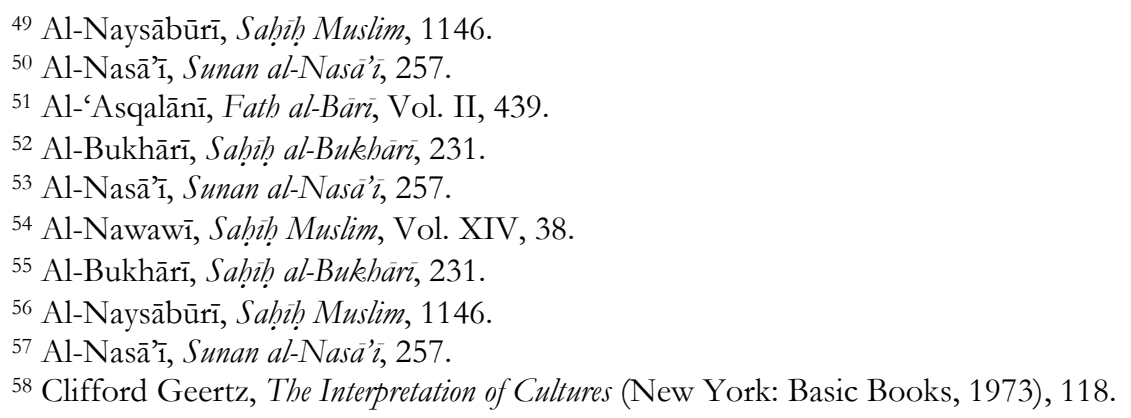


akulturasi dialogis antara hadis dan tradisi lokal Madura terjadi begitu panjang, sehingga asal-mula dan pencetusnya tidak mudah diungkap. Masyarakat Madura identik dengan sosio-religi yang kental, bahkan fanatik terhadap mazhab. Bila masyarakat Melayu yang identik dengan aforisme "adat basandi syarak, syarak basandi Kitabullah", maka masyarakat Madura identik dengan dua aforisme, yaitu "abhantal syahadat, asapo' iman, apajung Allab" (berbantal syahadat, berselimut iman, dan 'berpayung' Allah) dan "bhuppa', bhabuk, ghuru, rato" (bapak, ibu, guru, dan raja). Dua aforisme ini menunjukkan jiwa keislaman mereka serta ketakziman dan kepatuhan mereka kepada bapak, ibu, guru, dan raja. Poin yang terkait dengan inti persoalan artikel ini adalah kata "gburu" dalam aforisme ini, yang identik dengan guru informal, terutama kiai pesantren yang disegani, dipatuhi, dan diteladani dalam urusan sehari-hari, baik ekonomi, sosial, budaya, politik, ${ }^{59}$ maupun agama.

Meski kedekatan secara geografis dengan Jawa tidak bisa dinafikan ikut memengaruhi eksistensi tradisi pakaian baru pada hari raya di Madura, tetapi hipotesis bahwa tradisi ini berasal dari figur kiai juga tidak bisa dinafikan; kiai mempraktikan dan mengajarkannya, lalu masyarakat Madura meniru dan mempraktikkannya secara turuntemurun sebagai wujud kepatuhan mereka kepadanya. Meski hipotesis ini masih perlu dipecahkan dalam sebuah penelitian khusus, tetapi tradisi pakaian baru pada hari raya di Madura bisa dipastikan sebagai living hadith pada aspek matan yang terkait dengan kemanusiaan. Tradisi ini merupakan akulturasi dialogis-nirkekerasan antara Islam dan budaya lokal melalui resepsi masyarakat terhadap aspek performatif hadis, sehingga menjadi sebuah tradisi.

Sebuah tradisi mengandung nilai positif dan nilai negatif, baik tradisi yang muncul karena inisiatif murni manusia sebagai wujud kearifan lokal mereka maupun tradisi yang muncul karena anjuran agama. Pada mulanya, tradisi yang muncul karena anjuran agama hanya mengandung nilai positif karena ia bersumber dari Tuhan, tetapi pada perjalanan sejarahnya ia juga mengandung nilai negatif karena campur tangan manusia lintas kawasan dan generasi, sehingga kadang melabrak ajaran agama lainnya yang diekspresikan secara beragam, karena menurut Geertz semua ritual keagamaan yang

59 Ridwan Ahmad Sukri, 'Konsep 'Bapa' Babu' Guru Rato' pada Masyarakat Madura sebagai Wujud Pengalaman Sila ke-2 Pancasila", Jurnal Filsafat, Seri 30 (Oktober, 1999), 144-151. 
melibatkan perpaduan simbolis antara etos dan pandangan dunia pasti lebih pelik dan biasanya bersifat lebih publik. ${ }^{60} \mathrm{Hal}$ ini juga terjadi pada tradisi memakai pakaian baru pada hari raya; pada mulanya, ia diajurkan sebagai bentuk penghormatan terhadap ritus Islam, tetapi pada perjalanan sejarahnya ia kemudian menjadi ajang pamer dan pemborosan, sehingga melenceng dari ajaran Islam yang menyebabkan pola hidup konsumtif dan disintegrasi kehidupan sosial. Berdasarkan kuesioner, hal ini terjadi di Madura. Namun, di balik nilai negatif tersebut, tradisi ini juga mengandung nilai positif.

Di antara nilai positif tradisi ini yaitu: (a) kepatuhan terhadap salah satu anjuran Islam; (b) wujud penghormatan terhadap sebuah ritus Islam; (b) ekspresi kebahagiaan terhadap sebuah ritus Islam; (c) hadiah kasih sayang orang tua kepada anaknya; (d) pelestarian tradisi Islam; dan (e) pembedaan antara hari atau momentum tertentu dan hari atau momen lainnya. Berdasarkan lima nilai positif ini, tradisi memakai pakaian baru pada hari raya penting dilestarikan, karena selain bernilai ibadah karena dianjurkan dalam Islam, ia juga merupakan ekspresi kebahagiaan dan kasih sayang serta meningkatkan aktivitas perekonomian masyarakat secara signifikan melalui penjualan pakaian baru secara besar-besaran dalam skala nasional. Meski demikian, pelestarian tradisi ini perlu diimbangi dengan pola hidup yang positif, sehingga tidak terjebak pada perilaku pamer dan pemborosan. Selain itu, tokoh agama juga perlu mengingatkan masyarakat bahwa tradisi ini sebenarnya merupakan tradisi Islam dengan menyampaikan hadis terkait dan penjelasan yang baik, sehingga tradisi ini tidak disalahpahami dan tetap bisa dilestarikan tanpa mengubah jati diri mereka sebagai orang Madura.

\section{Penutup}

Penghormatan kepada ritus Islam dianjurkan. Idulfitri, Iduladha, dan salat Jumat termasuk dalam ritus Islam. Salah satu cara penghormatan kepada tiga ritus ini adalah memakai pakaian terbaik yang dimiliki. Pakaian terbaik identik dengan pakaian baru, sehingga ulama memahami tiga hadis sahih riwayat 'Abd Allah b. 'Umar yang diriwayatkan al-Bukhārī dalam Bāb fì al-Tdayn wa al-Tajammul fì di Kitāb al-T̄idayn dalam Sahīḥ al-Bukhārì, Muslim dalam Kitāb al-Libās wa al-Zinah dalam Saḥịh Muslim, dan al-Nasāà dalam Bāb al-Zinah li alİdayn di Kitāb Salāh al-T̃dayn dalam Sunan al-Nasā'ì sebagai anjuran

${ }^{60}$ Geertz, The Interpretation, 113. 
untuk memakai pakaian terbaik pada saat Idulfitri, Iduladha, dan salat Jumat.

Pandangan masyarakat Madura tentang tradisi pakaian baru pada hari raya di Madura beraneka-ragam, bahkan kontradiktif antara pandangan positif dan negatif, tergantung sudut pandang, pengamatan, dan pengalamannya, seperti bentuk partisipasi, syukur, dan antusiasme atas penyambutan dan perayaan hari besar Islam, simbol hari raya dan kesucian fitrah, hadiah atas puasa, kepuasan, pamer, kesombongan, dan pembedaan hari serta momentum.

Tradisi memakai pakaian baru pada hari raya di Madura merupakan living badith, karena keberadaannya diilhami oleh tiga hadis sahih riwayat 'Abd Allah b. 'Umar yang diriwayatkan al-Bukhārī, Muslim, dan al-Nasā̄', serta praktik Ibn 'Umar pada masa awal Islam, sehingga tradisi ini dianjurkan dalam Islam. Ia mencakup unsur kepatuhan, penghormatan serta ekspresi kebahagiaan atas ritus Islam, hadiah kasih sayang orang tua kepada anaknya, pelestarian tradisi Islam, dan pembedaan antara hari atau momentum tertentu dan hari atau momen lainnya.

\section{Daftar Pustaka}

'Āshūr (ibn), Muhammad al-Ṭāhir. Al-Taḥrì wa al-Tanwìr, Vol. 2. Tunisia: al-Dār al-Tūnisīyah li al-Nashr, 1984.

'Asqalānī (al), Aḥmad b. 'Alī b. Hajar. Fatḥ al-Bārì bi Sharḥ Saḥị̣ alBukhārī, Vol. II (Beirut: Dar al-Ma'rifah, t.th.

'Itr, Nūr al-Dīn. Manhaj al-Naqd fì 'Ulūm al-Hadìth. Damaskus: Dār alFikr, 1979.

Ali, Muhamad. "Kajian Naskah dan Kajian Living Qur'an dan Living Hadith." Journal of Qur'an and Hadith Studies, Vol. 4, No. 2 (2015).

Bāqī (al), Muḥammad Fu'ād 'Abd. Al-Mu'jam al-Mufahras li Alfāza alQur'àn al-Karim. Kairo: Dār al-Hadìith, 1364 H. - Al-Mu'jam al-Mufahras li Alfä̌r al-Hadith al-Nabawì, Vol. I dan VI. Leiden: Brill, 1936.

Bukhārī (al), Abū 'Abd Allāh Muhạmmad b. Ismāî̀l. Sahīḥ al-Bukhārī. Beirut: Dār Ibn Kathīr, 2002.

Dwi, Hutomo. "Sejarah Baru Serba Baru Saat Lebaran Sejak Zaman Kerajaan." Jadiberita. http://jadiberita.com/90801/sejarah-bajuserba-baru-saat-lebaran-sejak-zaman-kerajaan.html. 
Erwan. "Memakai Baju Baru", Buletinpintar. www.buletinpillar.org/renungan/memakai-baju-baru.

Geertz, Clifford. The Interpretation of Cultures. New York: Basic Books, 1973.

Hasanah, Hasyim. "Perayaan Imlek Etnis Tionghoa: Menakar Implikasi Psiko-Sosilogis Perayaan Imlek bagi Komunitas Muslim di Lasem Rembang." Jurnal Penelitian, Vol. 8, No. 1 (2014).

Hasbillah, Ahmad 'Ubaydi. "Objek Kajian Living Quran dan Hadis." https://id.123dok.com/document/zlr5v7oz-objek-kajianliving-quran-dan-hadis.html.

Kodiran. "Akulturasi sebagai Mekanisme Perubahan Kebudayaan." Humaniora, No. 8 (1998).

Madjid, Nurcholis. "Akulturasi Islam dan Budaya Lokal." Paramadina. https://paramadina.or.id/2015/08/07akulturasi-islam-danbudaya-lokal/.

Munawir. "Ahl Al-Hadith dan Ahl Al-Ra'y: Dari Konstruksi Metodologi Hingga Tipologi Pemahaman Hadis Dialektik." Mutawatir: Jurnal Keilmuan Tafsir Hadith, Vol. 9, No. 2 (2019).

Nasā̄ì (al), Abū 'Abd al-Raḥmān Aḥmad b. Shu'ayb b. 'Alī. Sunan alNasā̄i. Riyad: Maktabah al-Ma'ārif, t.th.

Nawawī (al). Sabīh Muslim bi Sharţ al-Nawawī, Vol. XIV. Kairo: alMațba'ah al-Mișriyah bi al-Azhar, 1929.

Naysābūrī (al), Abū al-Husayn Muslim b. al-Ḥajjāj al-Qushayrī. Sahīḥ Muslim. Riyad: Dār al-Mughnī, 1998.

Prijono, Sudarti. "Aspek Adaptasi dan Akulturasi Budaya di Situs Bumi Rongsok Tasikmalaya." Purbawidya: Jurnal Penelitian dan Pengembangan Arkeologi, Vol. 4, No. 2 (2015).

Qudsy, Saifuddin Zuhry. "Living Hadis: Genealogi, Teori, dan Aplikasi." Jurnal Living Hadis, Vol. 1, No. 1 (2016).

Rachman, Subhan MA dan Fuad Rahman. "The Dynamic of Malay Islamic Law: The Rise and Practices of Adat Bersendi Syarak, Syarak Bersendi Kitabullah in Jambi." Journal of Indonesian Islam, Vol. 11, No. 2 (2017).

Saefullah, Saad. "Ini Hukum Memakai Baju Baru Saat Idul Fitri." Islampos. https://www.islampos.com/ini-hukum-memakai-bajubaru-saat-idul-fitri-32127/. 
Sukri, Ridwan Ahmad. 'Konsep 'Bapa' Babu' Guru Rato' pada Masyarakat Madura sebagai Wujud Pengalaman Sila ke-2 Pancasila." Jurnal Filsafat, Seri 30 (1999).

Sumbulah, Umi. "Islam Jawa dan Akulturasi Budaya: Karakteristik, Variasi, dan Ketaatan Ekspresif." el Harakah, Vol. 14, No. 1 (2012).

Wallawī (al), 'Alī b. Ādam b. Mūsā al-Atyūbī. Dhakbirah al- 'Uqbā fì Sharḥ al-Mujtabā, Vol. XVII. Mekah: Dār Āl Barūm, 2003. 